\title{
DAPK1 wt Allele
}

National Cancer Institute

\section{Source}

National Cancer Institute. DAPK1 wt Allele. NCI Thesaurus. Code C60653.

Human DAPK1 wild-type allele is located in the vicinity of 9q34.1 and is approximately 211

$\mathrm{kb}$ in length. This allele, which encodes death-associated protein kinase 1, is a positive

mediator of gamma-interferon induced apoptosis and is also a tumor suppressor candidate. 